\title{
Cervid forage utilization in noncommercially thinned pon- derosa pine forests
}

\author{
MARY C. GIBBS, JONATHAN A. JENKS, CHRISTOPHER S. DEPERNO, BOK F. SOWELL, AND KURT J. JENKINS
}

Authors are former Graduate Research Assistant, Department of Wildlife and Fisheries Sciences, South Dakota State University, Brookings, S.D. 57007; Professor, Department of Wildlife and Fisheries Sciences, South Dakota State University, Brookings, S.D. 57007; Assistant Professor, Department of Forestry, North Carolina State University, Raleigh, N.C. 27695; Associate Professor, Department of Animal and Range Sciences, Montana State University, Bozeman, Mont., 59717; Research Biologist, Olympic Field Station, 600 East Park Avenue, Port Angeles, Wash. 98362.

\section{Abstract}

To evaluate effects of noncommercial thinning, utilization of forages consumed by elk (Cervus elaphus L.), mule deer (Odocoileus hemionus Raf.), and white-tailed deer (Odocoileus virginianus Raf.) was measured in ponderosa pine (Pinus ponderosa P. \& C. Lawson) stands in Custer State Park, S. D. Treatments consisted of unthinned (control; 22 to $32 \mathrm{~m}^{2} /$ ha basal area), moderately thinned (12 to $22 \mathrm{~m}^{2} / \mathrm{ha}$ basal area), and heavily thinned ( 3 to $13 \mathrm{~m}^{2} / \mathrm{ha}$ basal area) stands of ponderosa pine. During June, July, and August, 1991 and 1992, about 7,000 individual plants were marked along permanent transects and percent-weight-removed by grazing was ocularly estimated. Sample plots were established along transects and plants within plots were clipped to estimate standing biomass. Pellet groups were counted throughout the study area to determine summer habitat use of elk and deer. Diet composition was evaluated using microhistological analysis of fecal samples. Average percent-weightremoved from all marked plants and percent-plants-grazed were used to evaluate forage utilization. Standing biomass of graminoids, shrubs, and forbs increased $(P<0.05)$ from unthinned to moderately and heavily thinned stands. Utilization of graminoids and shrubs averaged less than $1 \%$ when measured as percent-weight-removed and percent-plants-grazed and did not differ $(P>0.05)$ across treatments. Forb use averaged less than $5 \%$ within sampling periods when measured as percentweight-removed and percent-of-plants grazed and did not differ among treatments. Results of pellet group surveys indicated that cervids were primarily using meadow habitats. When averaged over the 2 years, forbs were the major forage class in deer diets, whereas graminoids were the major forage class in diets of elk.

Key Words: Cervus elaphus, diets, forage standing biomass, mule deer, Odocoileus hemionus, Odocoileus virginianus, white-tailed deer

We thank G. C. Brundige and R. Walker at Custer State Park for their assistance during field work. N. Anderson and J. Auer helped with collection of field data. L. D. Flake, K. F. Higgins, B. J. Kernohan, and two anonymous reviewers made many helpful suggestions on this manuscript. Financial support for this research was provided by South Dakota Department of Game, Fish, and Parks (Federal Aid in Wildlife Restoration Act under Project No. W-75-R-33 Study No. 7552).

Manuscript accepted 7 Feb. 2004.
Resumen

Para evaluar los efectos del aclareo no comercial, se midió la utilización de forrajes consumidos por el alce (Cervus elaphus L.), el venado (Odocoileus hemionus Raf.) y el venado cola blanca (Odocoileus virginianus Raf.) en poblaciones de pino ponderosa (Pinus ponderosa P. \& C. Lawson) del Parque Estatal Custer en S. D. Los tratamientos consistieron de poblaciones de pino ponderosa sin aclareo (control; 22 a $32 \mathrm{~m}^{2} /$ ha área basal), moderadamente aclareadas (12 a $22 \mathrm{~m}^{2} / \mathrm{ha}$ área basal) y fuertemente aclareadas (3 a $13 \mathrm{~m}^{2} /$ ha área basal). Durante Junio, Julio y Agosto de 1991 y 1992 cerca de 7,000 plantas individuales fueron marcadas a lo largo de transectos permanentes y el porcentaje de peso removido por el apacentamiento se estimó en forma ocular. Se establecieron parcelas de muestreo a lo largo de los transectos y las plantas dentro de ellas fueron cortadas para estimar la biomasa en pie. Se contaron los grupos de pelets fecales a través del área de estudio para estimar el uso del hábitat en verano por el alce y el venado. La composición de la dieta se evaluó usando análisis microhistológico de muestras fecales. El promedio del porcentaje de peso removido de todas las plantas marcadas y el porcentaje de plantas apacentadas se usaron para evaluar lal utilización del forraje. La biomasa en pie de gaminoides, arbustos y hierbas se incremento $(P<\mathbf{0 . 0 5})$ de las poblaciones sin aclareo a las moderadamente y fuertemente aclareadas. La utilización de graminoides y arbustos promedio menos del $1 \%$ cuando se midió como porcentaje de peso removido y porcentaje de plantas apacentadas y no difirió entre tratamientos $(P>0.05)$. Cuando se midió como porcentaje de peso removido y porcentaje de plantas apacentadas el uso de hierbas promedio menos del 5\% dentro de los periodos de muestreo y no difirió entre tratamientos. Los resultados de los muestreos de grupos de pelets indicaron que los cervidos estuvieron usando principalmente los hábitats de praderas. Cuando se promediaron los dos años, las hierbas fueron la principal clase de forraje en las dietas de los venados, mientras que las graminoides fueron la principal clase de forraje en las dietas del alce.

Understory-overstory relationships have been studied extensively in ponderosa pine (Pinus ponderosa P. \& C. Lawson) forests throughout the western United States (Clary and Ffolliott 1966, McConnell and Smith 1970, Harlow 1984) as well as within the Black Hills of South Dakota (Pase 1958, Bennett et al. 1987, Bopray 1987, Uresk and Severson 1989). In all reported instances, thinning ponderosa pine increased forage production by reducing competition for light, moisture, and soil nutrients. 
Although thinning ponderosa pine forests increases forage yields, benefits to large mammals have been difficult to demonstrate. In mixed conifer forests of northeastern Oregon, elk (Cervus elaphus L.) sign was greater in clearcuts than in uncut forests, while areas that were selectively thinned (30\% of basal area removed) were used less than uncut areas (Edgerton 1972). Similarly, in eastern Arizona, deer sign increased following a reduction of overstory basal area from $41 \mathrm{~m}^{2} /$ ha to 7 $\mathrm{m}^{2} / \mathrm{ha}$ in mixed coniferous forests (Patton 1974). Conversely, Wallmo and Schoen (1980) concluded that deer in Alaska used overmature uneven-aged forests more heavily than young clearcuts or even-aged secondary growth forests.

Our primary objective was to evaluate effects of thinning practices on use of ponderosa pine forests by elk, mule deer (Odocoileus hemionus Raf.), and whitetailed deer (Odocoileus virginianus Raf.) in Custer State Park, (CSP) S.D., during the summers of 1991 and 1992. Secondary objectives were to: 1) compare standing biomass and forage utilization between unthinned, moderately thinned, and heavily thinned ponderosa pine stands in Custer State Park, 2) determine summer habitat use of big game in ponderosa pine forests of Custer State Park, and 3) identify key summer forages utilized by big game in ponderosa pine forests of Custer State Park. We hypothesized that there would be no differences between unthinned, moderately thinned, or heavily thinned pine stands relative to standing biomass and forage utilization by deer and elk in CSP. Additionally, we hypothesized that elk and deer would use habitat and summer forages similarly in unthinned, moderately, and heavily thinned ponderosa pine stands.

\section{Study Area}

Custer State Park is located in the southeastern Black Hills of western South Dakota. The Park is characterized by open prairies in the south and east and ponderosa pine dominated forests in the north and west. Grassy meadows interspersed with aspen (Populus tremuloides Michx.) and paper birch (Betula papyrifera Marsh.) naturally occur throughout the pine forest in bottom draws. Although ponderosa pine is the dominant overstory species, understory vegetation is highly variable and composed of many graminoid, forb, and shrub species. Common graminoids include carices
(Carex spp.), poverty oatgrass (Danthonia spicata (L.) Beauv.), and rough ricegrass (Oryzopsis asperifolia Michx.). Common forbs include bluebell (Campanula rotundifolia L.), goldenrod (Solidago spp.), western yarrow (Achillea millefolium L.), and vetchling (Lathyrus ochroleucus Hook.). Snowberry (Symphoricarpos albus (L.) Blake), common juniper (Juniperus communis L.), and kinnikinnick (Arctostaphylos uva-ursi L.) Spreng.) are abundant shrubs typical of the region (Richardson and Peterson 1974)

The study area included 2,640 ha of forest situated in the northwest corner of Custer State Park $\left(103^{\circ} 25^{\prime} 2^{\prime \prime} \mathrm{W}\right.$, $43^{\circ} 43^{\prime} 48^{\prime \prime} \mathrm{N}$ ), where unthinned, moderately thinned, and heavily thinned forests each accounted for equal portions of the study area. Generally, pine stands were thinned in blocks, leaving unthinned forests along the periphery. Within the study area, 28 management units, ranging from 24 to 88 ha, were thinned between January 1981 and April 1987; stands along the north and east were logged in 1991. Prior to thinning, units consisted of densely stocked ponderosa pine with basal areas that ranged from 22 to $32 \mathrm{~m}^{2} / \mathrm{ha}$. After moderate thinning, the units consisted of ponderosa pine stands with basal areas that ranged from 12 to $22 \mathrm{~m}^{2} /$ ha, while after heavy thinning, basal areas were reduced to 3 to $13 \mathrm{~m}^{2} / \mathrm{ha}$.

\section{Materials and Methods}

\section{Sampling Design}

Standing biomass, forage utilization, and cervid pellet densities were estimated in unthinned ( 22 to $32 \mathrm{~m}^{2} / \mathrm{ha}$ basal area), moderately thinned (12 to $22 \mathrm{~m}^{2} /$ ha basal area), and heavily thinned ( 3 to $13 \mathrm{~m}^{2} / \mathrm{ha}$ basal area) ponderosa pine stands. Six replicate stands of each treatment, 2 within each of 3 geographic blocks that partitioned the study area, were randomly selected from forest inventory maps and aerial photographs.

\section{Standing Biomass}

Standing biomass of understory vegetation was measured monthly during June, July, and August, 1991 and 1992 along four, 50-m transects established randomly along slope contours within a 4-ha study plot (24 transects per treatment, overall $n$ $=72$ transects) of uniform vegetation in each sample stand. Clipping of vegetation was conducted in three, $0.25 \mathrm{~m}^{2}$ plots placed $15 \mathrm{~m}$ apart along each transect; clipped plots were offset $2 \mathrm{~m}$ from the transect to avoid clipping marked plants used for utilization measurements. Graminoids and forbs were clipped at ground level, while current annual growth was clipped from all portions of shrub crowns that occurred within the clip plots (Carpenter et al. 1979). Clipped vegetation was sorted by species, dried ( $>24$ hours at $\left.40^{\circ} \mathrm{C}\right)$, and weighed $( \pm 0.01 \mathrm{~g})$. Data were averaged over transects within stands. Nomenclature for plant species followed Flora of the Great Plains (Great Plains Flora Association 1986).

\section{Forage Utilization}

Forage utilization was measured using a modification of the percent-weightremoved method described by Cook and Stubbendieck (1986:120). At meter intervals along transects within each treatment, colored nails were used to mark the nearest graminoid, forb, and shrub, within 1 meter of the transect. Each marked plant was identified to species and beginning 1 June, each plant was examined twice a month to determine if it had been grazed. If grazed, utilization was estimated ocularly as one of the following percent-weightremoved classes: $1-5 \%, 6-10 \%, 11-15 \%$, $16-20 \%, 21-30 \%, 31-40 \%, 41-50 \%$, $51-60 \%, 61-70 \%, 71-80 \%, 81-90 \%$, and $91-100 \%$ weight removed. To calibrate ocular estimations, samples were hand clipped and weighed before each sampling period and ocular estimations were regressed with sample weights using double sampling techniques (Cook and Stubbendieck 1986:245).

Over the 2 years, 3,915 individual forbs, 5,832 graminoids, and 4,422 shrubs were marked, including 34 species of forbs, 15 species of graminoids, and 12 species of shrubs (Gibbs 1993). In heavily and moderately thinned stands, 1,779 individual forbs, 2,172 graminoids, and 1,774 shrubs were marked, and 1,443 forbs, 2,015 graminoids, and 1,563 shrubs were marked, respectively. In unthinned stands, 710 individual forbs, 1,633 graminoids, and 1,080 shrubs were marked because fewer plants were available for marking.

\section{Diets}

Forage species consumed by deer and elk were identified using microhistological analysis of fecal samples (Stewart 1967) collected from the study area during May, June, July, and August in 1991 and 1992. Fresh fecal material was collected randomly throughout the study area and frozen until composited by species (deer and elk) and month (Jenks et al. 1990). Individual fecal groups were oven dried at 
$50^{\circ} \mathrm{C}$ (Hinnant and Kothmann 1988) and blended in a high-speed blender (Davitt and Nelson 1980, Jenks et al. 1989). Deer fecal samples were composited (Jenks et al. 1989) by blending equal weights $(1.0 \pm$ $0.01 \mathrm{~g}$ ) of 7 fecal samples in 1991 and 35 samples in 1992. Elk fecal samples were composited from equal weights of 15 samples in 1991, and 39 samples in 1992.

Microhistological examination of blended composited fecal samples was conducted by the Wildlife Habitat Laboratory at Washington State University, Pullman, Washington. Diet composition was determined using 5 slides/composited sample and 30 random observations/slide (Holechek and Vavra 1981, Jenks et al. 1996, Whysong and Miller 1987, Osborn et al. 1998). Forages comprising $>5 \%$ of diets were identified to species, whereas minor species comprising $<5 \%$ of diets were pooled by forage class (e.g., graminoids, forbs, shrubs). Diet composition was expressed as the percentage of total surface area in 150 microscope fields of view (Jenks et al. 1996, Osborn et al. 1998). Minor forages were pooled because precise rankings are difficult to obtain (Holechek and Vavra 1981).

\section{Pellet Densities}

Pellet groups were counted within $1 \mathrm{~m}$ of the 72 transects located in unthinned, moderately, and heavily thinned ponderosa pine stands. In addition to pine stands, 24 pellet group transects were established in meadows because deer and elk were observed using those areas. From June through August, pellet groups were counted twice per month and then removed from plots to avoid double counting during future surveys. Fecal groups of elk and deer were distinguished and recorded separately; pellet groups of white-tailed and mule deer were combined because of difficulty in distinguishing between species.

\section{Analytical Methods}

Forage utilization and diet data were analyzed by forage class (i.e., shrub, graminoid, and forb). Two methods were used to evaluate utilization. First, an average percent-weight-removed was calculated for transects (by forage class and/or species) within stands and a repeated measures ANOVA was used to test for differences between treatments. Orthogonal contrasts were used to compare between unthinned and thinned, and between moderate and heavily thinned treatments. Second, an average percent-plants-grazed was calculated as the number of plants grazed divided by the total number of plants marked (by forage class and/or species). Bonferroni confidence intervals (95\%) for proportions (Byers et al. 1984) were used to test for differences in utilization between unthinned and thinned, and between moderate and heavily thinned treatments.

Analysis of variance was used to test for treatment differences in standing biomass and pellet group densities between unthinned, moderately thinned, and heavily thinned pine stands. All data were combined for the 2 years of the study to reduce the chance of a Type I error (Sokal and Rohlf 1981:159) (i.e., combined data increased variation, which decreased the chance that differences in treatments would be detected). All analyses were performed using SYSTAT (Wilkinson 1990)

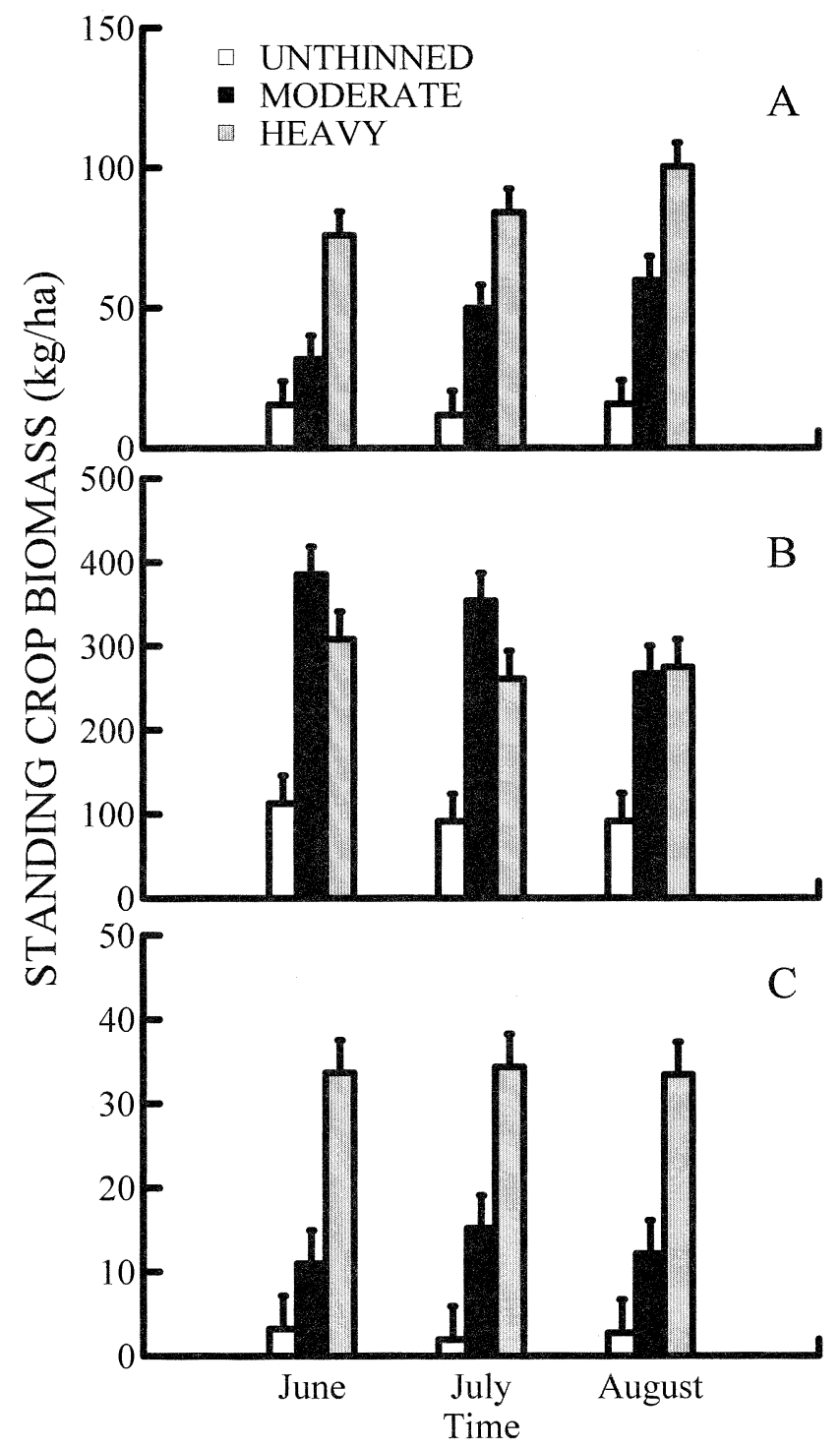

Fig. 1. Standing biomass (kg/ha + SEM) of graminoids (A), shrubs (B), and forbs (C) in unthinned, moderately thinned, and heavily thinned ponderosa pine stands in Custer State Park, S.D., 1991-92. and statistical comparisons were considered significant at $\mathrm{P} \leq 0.05$.

\section{Results}

When years, months, and species were combined, standing biomass averaged 401 $\mathrm{kg} / \mathrm{ha}$ in heavily thinned stands, $395 \mathrm{~kg} / \mathrm{ha}$ in moderately thinned stands, and 115 $\mathrm{kg} / \mathrm{ha}$ in unthinned stands. Graminoid standing biomass was higher $(\mathrm{P}<0.001)$ in heavily thinned (overall $\bar{x}=86 \mathrm{~kg} / \mathrm{ha}$ ) than in either moderately thinned (overall $\bar{x}=$ $47 \mathrm{~kg} / \mathrm{ha}$ ) or unthinned stands (overall $\bar{x}$ $=14 \mathrm{~kg} / \mathrm{ha}$ ) in all months (Fig. 1A). Shrubs contributed most to standing biomass in all treatments, comprising $78 \%$ of the total

\section{Standing Biomass}

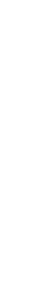


biomass of standing biomass (Fig. 1B). Shrub standing biomass was higher in heavily thinned (overall $\bar{x}=281 \mathrm{~kg} / \mathrm{ha}$ ) and moderately thinned (overall $\bar{x}=335$ $\mathrm{kg} / \mathrm{ha}$ ) than in unthinned (overall $\bar{x}=98$ $\mathrm{kg} / \mathrm{ha})$ stands $(\mathrm{P}<0.002)$ in all months. Forb standing biomass was higher in heavily thinned (overall $n=34 \mathrm{~kg} / \mathrm{ha}$ ) than in moderately thinned (overall $\bar{x}=13 \mathrm{~kg} / \mathrm{ha}$ ) and unthinned (overall $\bar{x}=3 \mathrm{~kg} / \mathrm{ha}$ ) pine stands $(\mathrm{P}<0.001)$ in all months (Fig. $1 \mathrm{C})$.

\section{Forage Utilization}

When years were combined, utilization of graminoids, which included predominantly poverty oatgrass, rough ricegrass, and carices, averaged less than $1 \%$ in both thinned and unthinned stands within each sampling period when measured as both percent-weight-removed and percentplants-grazed (Fig. 2A, 2B). No differences $(P>0.05)$ were identified between thinned and unthinned treatments relative to utilization of graminoids. However, trends across sampling periods were variable; utilization generally peaked during June-July sampling periods.

When years were combined, utilization of shrubs, predominantly spirea (Spiraea betulifolia Pallas), snowberry, and raspberry (Rubus idaeus L.), averaged less than $1 \%$ in each sampling period when measured as percent-weight-removed (Fig. $3 \mathrm{~A}$ ) and percent-plants-grazed (Fig. 3B) in both thinned and unthinned pine stands and did not differ $(P>0.05)$ between treatments. Shrub use was variable across sampling periods and methods.

When years were combined, utilization of forbs, predominantly bluebell, vetchling, pussytoes (Antennaria spp. Gaertn.), and silver-leaf scurfpea (Psoralea argophylla Pursh), averaged less than $4 \%$ in each sampling period when measured as percent-weight-removed (Fig. 4A) in thinned and unthinned pine stands and did not differ among treatments. Measured as percent-of-plants grazed within each sampling period, unthinned stands averaged less than $5 \%$ use and thinned stands averaged less than 3\% use (Fig. 4B); forb use did not differ among treatments.

\section{Diets}

A total of 66 species was identified using microhistological examination of composited fecal samples of deer (Gibbs 1993). When averaged over the 2 years, forbs were the major forage class in deer diets, comprising 36, 62, 60, and $60 \%$ of diets in May, June, July, and August, respectively. Forbs used most were bluebell, vetchling, pussytoes, and silver-leaf
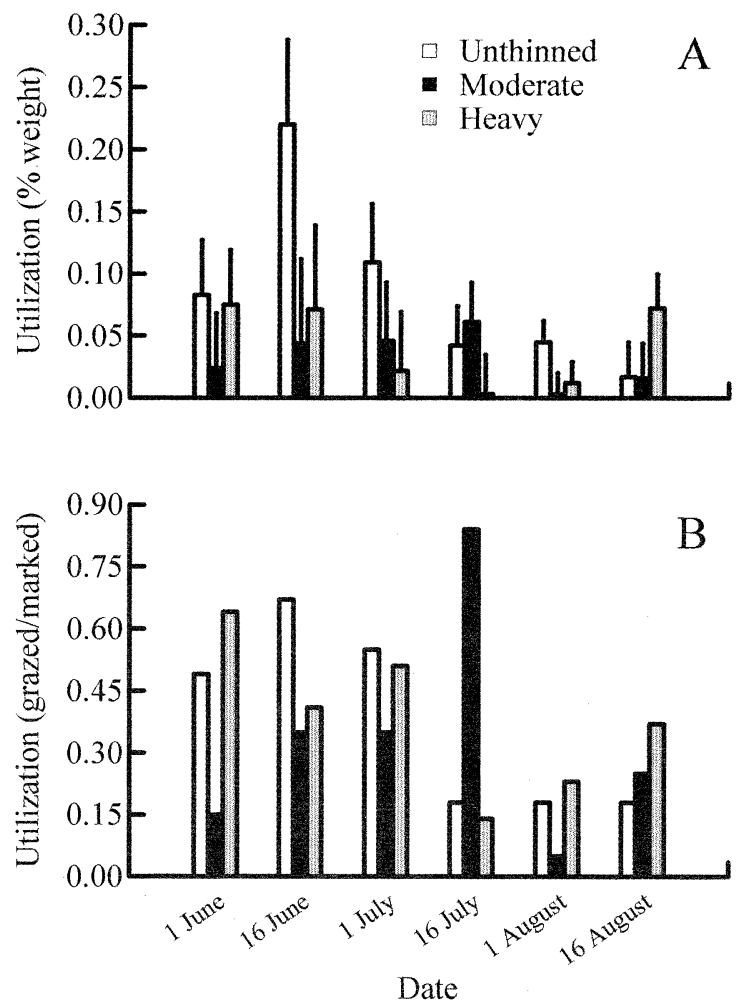

Fig. 2. Average (+ SEM) utilization of graminoids determined by percent-weight-removed (A) and percent-plants-grazed $(B)$ in unthinned, moderately thinned, and heavily thinned ponderosa pine stands in Custer State Park, S.D., 1991-92.

scurfpea. Graminoids were used most during early summer, comprising $39,27,27$, and $19 \%$ of diets in May, June, July, and August, respectively. Carices and Kentucky bluegrass (Poa pratensis L.) were the most important graminoids. Shrub species comprised 22, 10, 6, and $14 \%$ of diets in May, June, July, and August, respectively. Quaking aspen comprised the largest portion of browse in diets, while ponderosa pine was present in 5 of 7 composite samples, comprising as much as $6.7 \%$ of the diet in August 1991 (Gibbs 1993).

A total of 68 species was identified in composited fecal samples of elk (Gibbs 1993). Graminoids were the major forage class in diets of elk, particularly in early summer, comprising $82,81,50$, and $41 \%$ of diets in May, June, July, and August, respectively. Important graminoids were carices, poverty oatgrass, rough ricegrass, and Kentucky bluegrass. Forbs comprised $9,15,36$, and $39 \%$ of diets in May, June, July, and August, respectively. Red clover (Trifolium pratense L.) was the only forb to occur at levels of $5 \%$ or greater in any one month. Shrubs were infrequent $(<10 \%)$ in elk diets throughout summer (Gibbs 1993).

\section{Pellet Densities}

When months and years were combined, pellet group density was highest in meadows compared to the other treatments, averaging 600 elk and 275 deer pellet groups/ha ( $\mathrm{P}<0.001$; Fig. 5). Elk pellet group density was higher $(P=0.01)$ in heavily thinned stands (353 groups/ha) than in unthinned stands (168 groups/ha); however, deer pellet group density was similar $(\mathrm{P}>0.05)$ between treatments $(138$ and 135 groups/ha, respectively).

\section{Discussion}

Standing biomass ranged from 115 $\mathrm{kg} / \mathrm{ha}$ in unthinned pine to $401 \mathrm{~kg} / \mathrm{ha}$ in heavily thinned pine, and was similar to other studies conducted in the Black Hills region. Severson and Boldt (1977) concluded that total annual production was approximately 5 times higher in heavily thinned stands than in unthinned stands, and Pase (1958) stated that understory production ranged from $67 \mathrm{~kg} / \mathrm{ha}$ (air-dry weight) under dense unthinned stands, to $694 \mathrm{~kg} / \mathrm{ha}$ under thinned timber stands with $40 \%$ crown cover. 

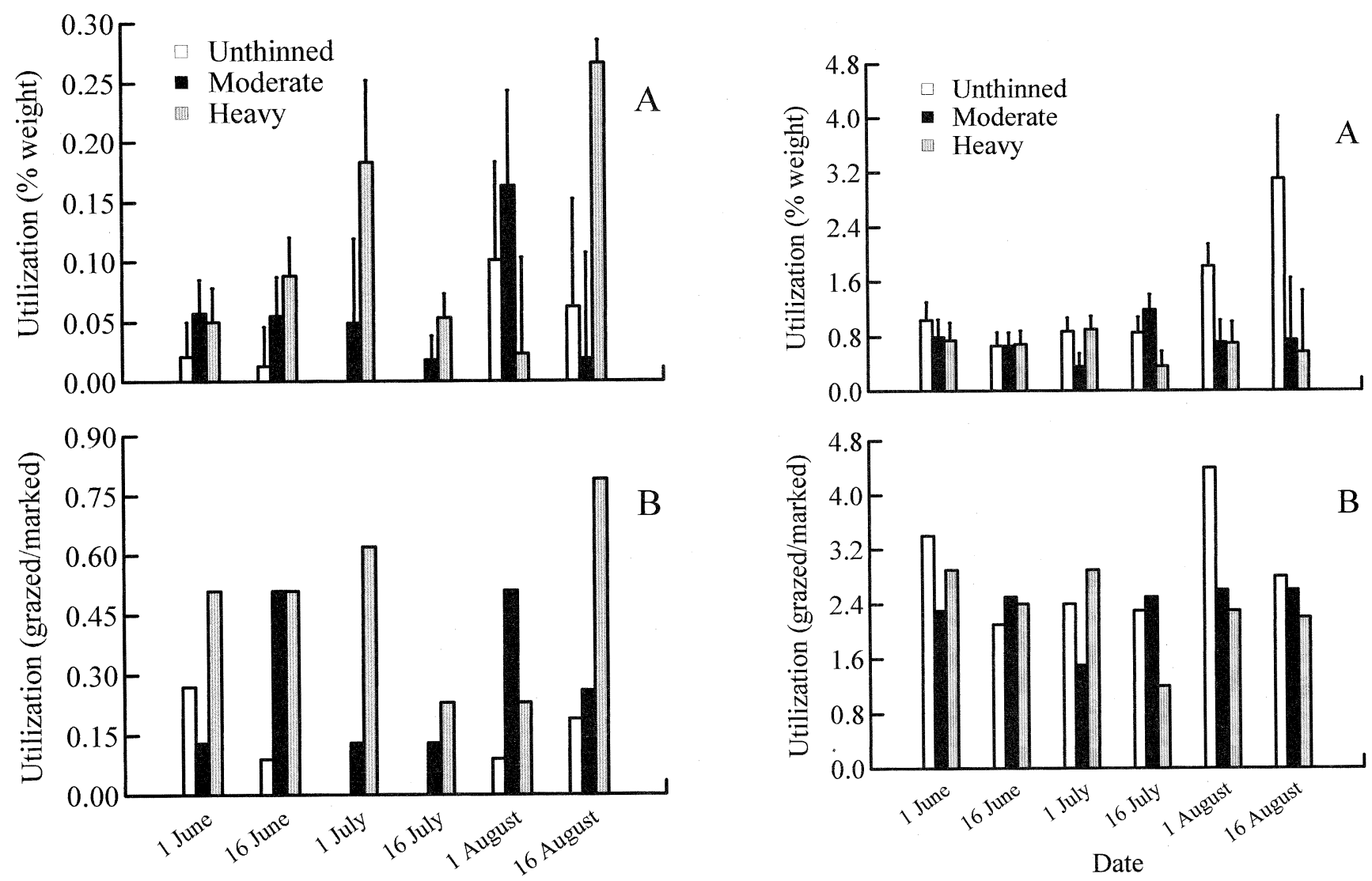

Date

Fig. 3. Average (+ SEM) utilization of shrubs determined by percentweight-removed (A) and percent-plants-grazed $(B)$ in unthinned, moderately thinned, and heavily thinned ponderosa pine stands in Custer State Park, S.D., 1991-92.

Fig. 4. Average (+ SEM) utilization of forbs determined by percent-weight-removed $(A)$ and percent-plants-grazed $(B)$ in unthinned, moderately thinned, and heavily thinned ponderosa pine stands in Custer State Park, S.D., 1991-92.

Heavily thinned stands exhibited a standing biomass 2.9 times greater in shrubs, 6.1 times greater in graminoids, and 13.0 times greater in forbs than standing biomass in unthinned stands. Similarly, moderately thinned stands had a standing biomass 3.4 times greater in shrubs, 3.4 times greater in graminoids, and 4.9 times greater in forbs than standing biomass in unthinned stands. These results are consistent with established overstory-understory relationships (Pase 1958, Harlow 1984, Uresk and Severson 1989) and indicated that thinning operations were delivering vegetative responses predicted for this region.

In this study, forbs and graminoids increased in standing biomass more in thinned stands than did shrubs. Pase (1958) and McConnell and Smith (1970) also noted the largest increase in biomass after thinning resulted from the response of graminoids and forbs. In our study, shrubs comprised the majority of standing biomass $(78 \%)$; kinickinick accounted for
$85 \%$ of shrub standing biomass. Shrub biomass was greater in moderately thinned stands than in heavily thinned stands, possibly because kinickinick was more prevalent in moderately thinned areas. Pase (1958) noted that kinickinick comprised $79 \%$ of shrub biomass in stands thinned to 20-39\% crown cover and Uresk and Severson (1989) indicated that kinickinick composed 70 to $99 \%$ of shrub biomass across all growing stock levels in the Black Hills.

Utilization of forage was low in both unthinned and thinned pine stands throughout the summer. Forage removal totaled $10 \%$ of $115 \mathrm{~kg} / \mathrm{ha}$ of available forage in unthinned pine stands. Forage removal totaled $5.3 \%$ of $398 \mathrm{~kg} / \mathrm{ha}$ of available forage in thinned stands. Utilization (percent-plants-grazed) of principal graminoids during summer months was considerably lower (1\%) than was estimated in southern Yellowstone National Park ( $\bar{x}=23 \%$; Boyce 1989:97); possibly due to lower animal density in Custer State Park.
Collins (1977) documented that when elk occupy more productive and species diverse habitats, they are less likely to move in search of preferred forage. Thus, deer and elk would be expected to consume more forage in thinned than unthinned areas because of greater standing biomass in these stands. Conversely, in unthinned stands, cervids would need to invest more time and energy searching for fo ge because of lower standing biomass. Although a higher level of biomass was removed in thinned than unthinned stands, pellet group density was not greater in these areas. Moreover, forage availability was 3.5 times greater in thinned areas than unthinned stands, while the amount of forage removed was 1.8 times greater, suggesting that thinned habitats received less foraging activity than expected.

Although varying rates of digestion and food passage among different forages bias fecal diet analysis (Smith and Shandruk 1979, Henley et al. 2001), relative abundance of key forage species can be reasonably estimated by fecal analysis (Holechek 


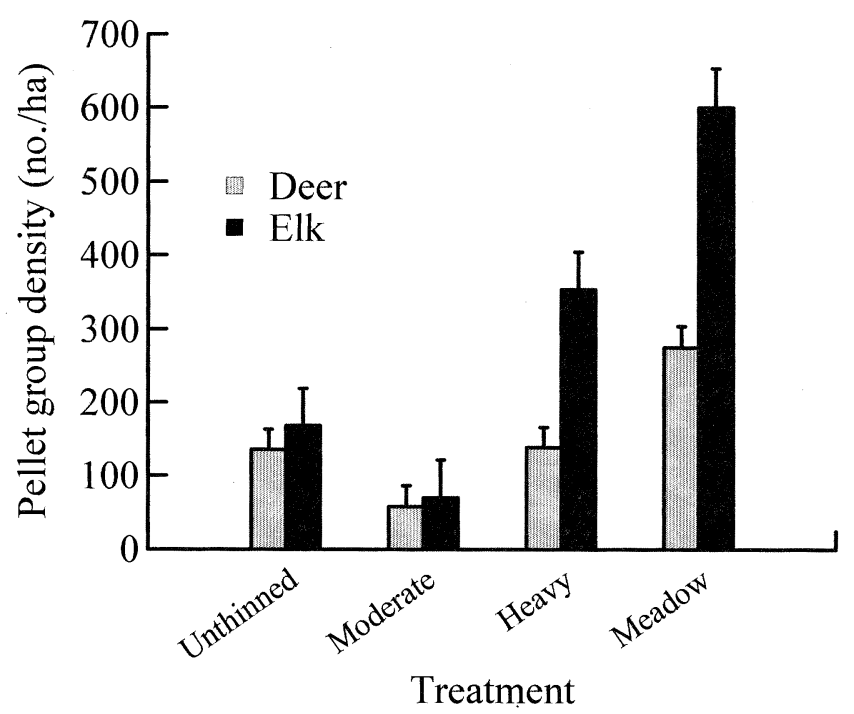

Fig. 5. Pellet group densities (+ SEM) of deer (white-tailed and mule) and elk in unthinned, moderately thinned, and heavily thinned ponderosa pine stands and aspen meadows in Custer State Park, S.D., 1991-92.

and Vavra 1981, McInnis et al. 1983). Deer diets in Custer State Park were dominated by forbs. Other studies also have noted graminoids and forbs as important to deer in early spring with shrubs becoming increasingly important as the summer progresses (Smith and Julander 1953, Dusek 1975, Carpenter et al. 1979, Bartmann 1983, Jenks et al. 1996).

Elk diets in Custer State Park (CSP) were dominated by graminoids, especially carices, poverty oatgrass, rough ricegrass, and Kentucky bluegrass. Jost et al. (1999) indicated that diets dominated by graminoids such as those observed in this study provided little nutritionally to elk in Ontario. However, other studies of elk foraging habits have indicated that graminoids were the major forage class consumed in summer diets (Kufeld 1973, Hansen and Clark 1977, Hobbs et al. 1979, Baker and Hobbs 1982). Wydeven and Dahlgren (1983) reported carices were principal forages consumed by elk in the southern Black Hills. In our study, forbs, primarily clover, increased in importance in diets in July and August, similar to diets of Rocky Mountain elk during summer (Kufeld 1973).

Pellet group counts are biased in favor of habitats used during activity periods (i.e., traveling from bed sites to feeding areas) (Progulske and Duerre 1964, Collins and Urness 1981). Nevertheless, pellet group counts can provide valid and useful rankings of relative selection (Neff 1968, Leopold et al. 1984, Loft and Kie 1988). Pellet group counts were highest in meadows, which were characterized by graminoids: rough ricegrass, poverty oat- grass, Kentucky bluegrass, and carices (Gibbs 1993). Also, primary forbs consumed by deer and elk (vetchling and clover) were frequently located in meadows and aspen comprised as much as $10 \%$ of deer diets. Moderately and heavily thinned areas offered similar cover (Gibbs 1993) but lower forage availability than meadows. Thinned areas might not be as attractive for foraging as were meadows to elk and deer.

Reynolds (1966) concluded that elk pellet group density was highest in meadows, while deer pellet group density was about the same in openings and adjacent forest. Edgerton (1972) and Patton (1974) concluded deer and elk use was highest in clearcut openings in forests due to increased forage production. Edgerton (1972) concluded that deer and elk pellet group density was higher in unthinned mixed conifer forest than in thinned stands. Furthermore, in central Colorado, deer use increased only in the most heavily thinned areas, while elk did not respond to thinning (Crouch 1986). In CSP, unthinned forests accounted for about onethird of the habitat with the remainder being thinned or recently logged. Areas that provide essential thermal and hiding cover (e.g., unthinned stands) possibly become more important where availability of these habitats is more limited.

\section{Management Implications}

Noncommercial thinning of ponderosa pine stands in Custer State Park increased understory standing biomass. Thinning benefits deer and elk by providing structural diversity and increasing the diversity and biomass of forages. However, assuming that an increase in forage biomass will translate into an increase in numbers of cervids may be presumptuous. The quality of cover and forage required by elk and deer are often not provided by forests thinned to levels recommended for ponderosa pine in the western U.S. (Lyon and Ward 1982). Consequently, thinned stands may not receive increased use by cervids because of reduced horizontal cover.

The extent to which food is a limiting factor will determine if cervids benefit from thinning forests. Elk and deer populations in this area did not increase forage utilization in thinned pine forest as expected based on increased forage availability, which suggested that forage was not limiting. Nevertheless, thinning did positively affect forage availability in pine stands as total forage removed from thinned stands was higher than in unthinned stands. Additionally, results from fecal analysis and pellet group surveys indicated that elk and deer were primarily foraging in meadows that were scattered throughout the forests within Custer State Park. Mesic habitats, such as meadows, likely provide higher standing biomass and quality of preferred forages when compared to thinned pine stands. Consequently, use of forage in thinned pine stands would not be maximal until production in meadow habitat becomes limited.

\section{Literature Cited}

Baker, D.L. and N.T. Hobbs. 1982. Composition and quality of elk summer diets in Colorado. J. Wildl. Manage. 46:694-703.

Bartmann, R.M. 1983. Composition and quality of mule deer diets on pinyon-juniper winter range, Colorado. J. Range Manage. 36:534-541.

Bennett, D.L., G.D. Lemme, and P.D. Evenson. 1987. Understory herbage production of major soils within the Black Hills of South Dakota. J. Range Manage. 40:166-170.

Bopray, K.J. 1987. Impact of ponderosa pine thinning and slash management on the herbage production of selected soils in Custer State Park. M.S. Thesis, South Dakota State Univ., Brookings, S.D.

Boyce, M.S. 1989. The Jackson elk herd. Cambridge University Press, New York, N.Y.

Byers, C.R., R.K. Steinhorst, and P.R. Krausman. 1984. Clarification of a technique for analysis of utilization-availability data. J. Wildl. Manage. 48:1050-1053.

Carpenter, L.H., O.C. Wallmo, and R.B. Gill. 1979. Forage diversity and dietary 
selection by wintering mule deer. J. Range Manage. 32:226-229.

Clary, W.P. and P.F. Ffolliott. 1966. Differences in herbage-timber relationships between thinned and unthinned ponderosa pine stands. USDA For. Serv. Res. Note RM158. Rocky Mtn. For. and Range Exp. Sta., Fort Collins, Colo.

Collins, W.B. 1977. Diet composition and activities of elk on different habitat segments in the lodgepole pine type, Uinta Mountains. M.S. Thesis, Utah State University, Logan, Ut. 74pp.

Collins, W.B. and P.J. Urness. 1981. Habitat preferences of mule deer as rated by pelletgroup distributions. J. Wildl. Manage. 45:969-972.

Cook, C.W. and J. Stubbendieck. 1986. Range research: Basic problems and techniques. Society for Range Management Denver, Colo.

Crouch, G.L. 1986. Effects of thinning polesized lodgepole pine on understory vegetation and large herbivore activity in central Colorado. USDA Forest Serv. Res. Note RM-268. Rocky Mtn. Forest and Range Exp. Sta., Fort Collins, Colo

Davitt, B.B. and J.R. Nelson. 1980. A method of preparing plant epidermal tissues for use in fecal analysis. Circ. 0628, Coll. Agr. Res. Cent., Washington State University, Pullman, Wash

Dusek, H.L. 1975. Range relations of mule deer and cattle prairie habitat. J. Wildl. Manage. 39:605-616.

Edgerton, P.J. 1972. Big game use and habitat changes in a recently logged mixed conifer forest in northeastern Oregon. Proc. Ann. Conf. Western Assoc. State Game and Fish Comm. 52:239-246.

Gibbs, M.C. 1993. Big game habitat utilization in noncommercially thinned ponderosa pine in Custer State Park. M.S. Thesis. South Dakota State Univ., Brookings, S.D.

Great Plains Flora Association. 1986. Flora of the Great Plains. University of Kansas Press, Lawrence, Kan.

Hansen, R.M. and R.C. Clark. 1977. Foods of elk and ungulates at low elevations in northwestern Colorado. J. Wildl. Manage. 41:76-80.

Harlow, R.F. 1984. Habitat evaluation, p. 601-628. In: L. K. Halls (ed.) White-tailed deer: ecology and management. The Wildlife Management Institute, Washington, D.C.

Henley, S.R., D.G. Smith, and J.G. Raats. 2001. Evaluation of 3 techniques for determining diet composition. J. Range Manage. 54:582-588

Hinnant, R.T. and M.M. Kothmann. 1988. Collecting, drying, and preserving feces for chemical and microhistological analysis. J. Range Manage. 41:168-171.

Hobbs, N.T., D.L. Baker, J.E. Ellis, and D.M. Swift. 1979. Composition and quality of elk diets during winter and summer: a preliminary analysis. p. 47-53. In: M.S. Boyce and L.D. Hayden-Wing (eds.) North American elk: ecology, behavior and man- agement. University of Wyoming, Laramie, Wyo.

Holechek, J.L. and M. Vavra. 1981. The effect of slide and frequency observation numbers on the precision of microhistological analysis. J. Range Manage. 34:337-338.

Jenks, J.A., R.B. Soper, R.L. Lochmiller, and D.M. Leslie, Jr. 1990. Effect of exposure on nitrogen and fiber characteristics of white-tailed deer feces. J. Wildl. Manage. 54:389-391.

Jenks, J.A., D.M. Leslie, Jr., R.L Lochmiller, M.A. Melchiors, and F.T. McCollum, III. 1996. Competition in sympatric white-tailed deer and cattle populations in southern pine forests of Oklahoma and Arkansas, USA. Acta Theriologica. 41:287-306.

Jenks, J.A., D.M. Leslie, Jr., R.L. Lochmiller, M.A. Melchiors, and W.D. Warde. 1989. Effect of compositing samples on analysis of fecal nitrogen. J. Wildl. Manage. 53:213-215.

Jost, M.A., J. Hamr, I. Filion, and F.F. Mallory. 1999. Forage selection by elk in habitats common to the French River Burwash region of Ontario. Can. J. Zool. 77:1429-1438

Kufeld, R.C. 1973. Foods eaten by the Rocky Mountain elk. J. Range Manage. 26:106-113.

Leopold, B.D., P.R. Krausman, and J.J. Hervert. 1984. Comment: The pellet-group census technique as an indicator of relative habitat use. Wildl. Soc. Bull. 12:325-326.

Loft, E.R. and J.G. Kie. 1988. Comparison of pellet-group and radio triangulation methods for assessing deer habitat use. J. Wildl Manage. 52:524-527.

Lyon, J.L. and A.L. Ward. 1982. Elk and land management. p. 443-477. In: J.T. Ward and D.E. Toweill (eds.) Elk of North America: ecology and management. Stackpole Books, Harrisburg, Penn

McConnell, B.R. and J.G. Smith. 1970 Response of understory vegetation to ponderosa pine thinning in eastern Washington. J. Range Manage. 23:208-212.

McInnis, A., M. Vavra, and W. Krueger. 1983. A comparison of four methods to determine the diets of large herbivores. J. Range Manage. 36:302-307.

Neff, D.J. 1968. The pellet-group count technique for big game trend, census, and distribution: A review. J. Wildl. Manage. 23:597-614.

Osborn, R.G. , J.A. Jenks, and W.F. Jensen. 1998. Diet composition of elk in the Northern Great Plains of North Dakota as determined from rumen and fecal analysis. Prairie Nat. 29:237-248.

Pase, C.P. 1958. Herbage production and composition under immature ponderosa pine stands in the Black Hills. J. Range Manage. 11:238-243.

Patton, D.R. 1974. Patch cutting increases deer and elk use of a pine forest in Arizona. J. For. 72:764-766

Progulske, D.R. and D.C. Duerre. 1964 Factors influencing spotlighting counts of deer. J. Wildl. Mange. 28:27-34
Reynolds, H.G. 1966. Use of ponderosa pine forest in Arizona by deer, elk, and cattle. USDA For. Serv. Res. Note RM-63. Rocky Mtn. For. and Range Exp. Sta., Fort Collins, Colo.

Richardson, A.H. and L.E. Peterson. 1974. History and management of South Dakota deer. South Dakota Department of Game Fish, and Parks Publication Bulletin No. 5. Pierre, S.D.

Severson, K.E. and C.E. Boldt. 1977. Options for Black Hills forest owners: Timber, forage, or both. Rangeman's J. 4:13-15.

Smith, A.D. and L.J. Shandruk. 1979 Comparison of fecal, rumen, and utilization methods for ascertaining pronghorn diet. $\mathbf{J}$. Range Manage. 32:275-279.

Smith, J.G. and O. Julander. 1953. Deer and sheep competition in Utah. J. Wildl. Manage. 17:101-112.

Sokal R.R. and F.J. Rohlf. 1981. Biometry. W. H. Freeman and Company, New York, N.Y.

Sparks, D.R. and J.C. Malechek. 1968. Estimating percentage dry weight in diets using a microscopic technique. J. Range Manage. 21:264-265.

Stewart, D.R.M. 1967. Analysis of plant epidermis in feces: a technique for studying the food preferences for grazing herbivores. $\mathrm{J}$ Appl. Ecol. 4:83-111.

Uresk, D.W. and K.E. Severson. 1989. Understory-overstory relationships in ponderosa pine forests, Black Hills, South Dakota. J. Range Manage. 42:203-208.

Wallmo, O.C. and J.W. Schoen. 1980. Response of deer to secondary forest succession in southeast Alaska. For. Sci. $26: 448-462$.

Whysong, G.L. and W.H. Miller. 1987. An evaluation of random and systematic plot placement for estimating frequency. J. Range Manage. 40:475-479.

Wilkinson, L. 1990. SYSTAT: The system for statistics. SYSTAT, Inc., Evanston, Ill.

Wydeven, A.P. and R.B. Dahlgren. 1983. Food habits of elk in the northern Great Plains. J. Wildl. Manage. 47:916-924. 